\title{
Development and validation of a multi-dimensional customer-based scale to measure perceptions of Corporate Social Responsibility (CSR)
}

\begin{abstract}
Purpose - Based on a review of previous literature that revealed a gap in the measurement of corporate social responsibility (CSR) from a customer perspective, in this paper the authors propose a multi-dimensional scale to measure customer perceptions of CSR.

Design/methodology/approach -Using a systematic development process, the scale items were generated through the review of CSR literature and the opinion of academic experts. The scale was validated using data collected from 393 customers of the telecom industry. Data was initially subjected to exploratory factor analysis to identify the underlying scale dimensions. Confirmatory factor analysis was also conducted to validate the scale, testing for reliability, convergent and discriminant validity.

Findings - The resulting scale is compounded of 30 items that load on 5 dimensions: developmental, ethical, relationship-building, responsiveness and information-sharing responsibilities.

Practical implications - The proposal of reliable measurement tools for evaluating customer perceptions is especially relevant for companies because of their significant role in influencing the design and implementation of corporate actions. Along this line, the multi-dimensional scale developed in this study helps scholars and practitioners to better understand customer perceptions of the CSR actions that companies implement to improve these stakeholders' satisfaction. In doing so, the scale is especially useful for companies to measure how well they respond to customer needs in their daily routines.

Originality/value - There is a significant lack of research into the development of reliable and valid tools to measure CSR from a customer perspective. The contribution of this study focuses on the identification of the 5 dimensions that determine CSR towards customers while it also provides a detailed scale to measure customer perceptions of these CSR dimensions.
\end{abstract}

\section{Keywords}

Corporate Social Responsibility, Customers, Scale Development, Scale Validation

\section{Introduction}

Corporate Social Responsibility (henceforth referred to as CSR) is a business imperative in today's global marketplace. A company may engage in various types of actions, including CSR, to enhance its competitive position. In today's socially conscious market environment, CSR initiatives have become a significant component of most global business agendas. When executed well, CSR initiatives benefit both consumers and organizations (Lim, Sung, \& Lee, 2018). Thus, the concept of CSR has been around for quite some time (Turker, 2009). It has been studied in different contexts and its impact on the business, government, and society is well documented. when the firm invests in CSR, consumers become aware of this improvement in the firm's product development and manufacturing capabilities and expect the quality of the firm's new product to be higher (Bhardwaj, Chatterjee, Demir, \& Turut, 2018).

Along this line, it is generally accepted that the measurement of CSR holds significant importance for researchers and practitioners and some scholars have even argued that the real question concerning CSR is whether valid and reliable measures can be developed (Carroll, 2000). Nevertheless, the CSR field has been criticized for being too broad and complicated to actually allow researchers to develop solid and reliable single measurement tools (Öberseder et al., 2014). One of the reasons for this difficulty in measurement is that CSR means something, but not always the same thing to everybody. CSR does not mean the same thing for all stakeholders as it does not mean the same in every industry. Thus, most of the multidimensional measurement tools that have been proposed so far, which are generally intended to be applicable to any research setting (even involving numerous stakeholders and dispersed CSR actions), are not appropriate as decision instruments for managers (Maignan \& Ferrell, 2000; Turker, 2009; Gallardo \& Sánchez, 2014). 
Some scholars have preferred to define CSR on a limited basis, only referring to ethical or philanthropic corporate responsibilities (Pérez et al., 2013). As a result, a large number of studies can be found that have proposed to explore CSR through one-dimensional measurement tools (Pérez et al., 2013). However, these tools represent only one dimension of CSR (Maignan \& Ferrell, 2000) and thus limit the possibility of delving into different aspects of CSR and fall far apart from the broad CSR conception that prevails in literature and that also includes economic responsibilities (Brown \& Dacin, 1997; Sen \& Bhattacharya, 2001). All in all, new tools are needed that go deeper into the definition and measurement of specific dimensions of the multidimensional CSR construct and that allow researchers to evaluate stakeholder perceptions concerning CSR actions better. Hence, scholars have called for intensified efforts to develop appropriate and specific measurement tools (Dzansi \& Pretorius, 2009; Pérez et al., 2013; Fatma et al., 2014).

A limiting feature of the past CSR research is that the frequent conceptualization and measurement of CSR that involved a single aspect of CSR such as community involvement, fairness of employment, or business ethicality (Park, Lee, \& Kim, 2014). Park, Kim, \& Kwon (2017) have called for researchers to explore the factors associated with consumer perceptions of CSR (Park, Kim, \& Kwon, 2017). One vital issue that seems to have been often neglected in CSR literature is that customers, as one of the key stakeholders of companies, can play a crucial role in ensuring the success of CSR actions, leading companies to economic gains (Quazi et al., 2016). For instance, engaging in customer-related CSR actions can result in numerous benefits such as customer satisfaction and positive word-of-mouth (Sen et al., 2006), among others. Customerrelated issues have been widely researched in conceptual and empirical literature. However, CSR towards customers has received limited attention, resulting in calls for advancement of this type of research, particularly in empirical terms (Vitell, 2015). Furthermore, research on the specific perceptions and opinions of customers concerning CSR has been scarce so far (Pérez et al., 2013). This limitation of previous research is evident by the fact that, after an extensive review of 44 tools that have been suggested in literature to measure stakeholders' perceptions of CSR, the authors of this paper found that only 8 were based on customer perceptions (please check the following sections for further information on current tools to measure perceptions of CSR).

Based on the gaps identified in previous literature, the goal of this paper is to develop and validate a new tool to measure CSR towards customers based on data collected from a sample of 393 customers in the Pakistan telecom industry. In this regard, the study aims to answer questions such as how companies can be more socially responsible towards their customers or what CSR actions are most likely to enhance customer perceptions of companies' CSR significantly. In addition to the previously mentioned contributions, this paper also contributes to previous literature by exploring CSR and customer perceptions in a research context that has been scarcely explored so far. The extant research on CSR measurement focuses mostly on the context of developed countries such as USA, Australia, UK or Canada, among others, and few empirical studies focus on the developing countries (Palihawadana, Oghazi, Liu, 2016). CSR remains a relatively new concept in Asia (Lim, Sung, \& Lee, 2018). It is generally accepted that developed and developing countries have different contextual characteristics, therefore, measurement tools developed in the developed countries may not be helpful to managers in the developing world. Changing cultural context may affect how customers expect companies to behave. Thus, the CSR agenda and challenges in developing countries may be different from those of the developed world. The scale proposed in this paper is originally developed and tested in Pakistan. On the other hand, the study is based on customers in the telecom industry, which is a research setting that has been 
not explored in depth so far. Nevertheless, telecom operators provide services that are now categorized as a basic need for customers and society. Thus, testing the CSR scale in this context may contribute to a better understanding of customer expectations concerning the CSR of service companies.

The remainder of the paper is structured as follows. The paper starts by discussing the multidimensional character of CSR towards customers. Afterwards, an in-depth review of the measurement tools that have been previously proposed to evaluate customer perceptions of CSR is presented and their limitations are discussed. In the method and findings section, the research setting and the procedure established to develop the scale is explained. The results concerning the reliability, convergent, and discriminant validity of the tool are also presented in this section. The paper concludes with a discussion of the most relevant insights provided by the study, followed by the implications, limitations and future lines of research derived from it.

\section{Literature review}

\section{CSR towards customers: Why and how?}

CSR is an elusive concept. Its complexity is rooted in the different understanding of this concept over the time and among different stakeholders, which has changed as a consequence of the evolution in the nature of businesses and the numerous advances in society. Thus, and although the expanding literature on this issue provides a clearer understanding now, it is still problematic to find a commonly accepted definition of CSR (Turker, 2009).

One of the earliest definitions came from Bowen (1953). He referred to CSR as the obligation of businessmen to pursue those policies, to make those decisions, or to follow those lines of action that are desirable in terms of the objectives and values of our society. Nevertheless, throughout modern history many adaptations of this definition have been made. For instance, McWilliams and Siegel (2001) defined CSR as actions that appear to further some social good, beyond the interests of the company and that which is required by the law. Along this line, scholars have interpreted CSR as the company's obligation to maximize its social impact by seeking a balanced three-bottom line: economic, environmental, and social sustainability (Ferreira \& de Oliveira, 2014). Also, The Commission of the European Communities (2003) highlights that CSR relates to how a company is accountable for its impact on all relevant stakeholders. In addition to these definitions, it is also important to note that CSR refers to a company's voluntarily adopted obligation to constituent groups in society other than shareholders, such as customers, employees or suppliers, among others (Jones, 1980). Thus, this concept refers to corporate actions that are undertaken voluntarily without any governmental/legal enforcement (McWilliams \& Siegel, 2001).

Customers are one of the most important stakeholders for companies and the power of a brand lies in what customers see, hear, feel and learn about it as a result of their experiences over time. This shows that the power of a brand resides in what customers have in mind concerning that brand and the company. CSR especially influences customers when companies face an intensely competitive business environment with increasing customer expectations (Yeh, 2015). Competitive environments encourage companies to develop the capability of understanding their customers' demands better, becoming more responsive to customers' needs, rationales and beliefs 
(Sen \& Bhattacharya, 2001). In this context, CSR seeks to create competitive advantages by positioning products/services in the minds of customers through the building of strong corporate reputations based on economic, environmental and social actions (Boehe \& Cruz, 2010). Based on all these ideas, in the present study CSR towards customers is referred to as the voluntary and continuing commitment by the company to behave ethically and take business decisions that are linked to building strong relationships with customers through respect for them and compliance with their requirements (Pérez et al., 2013; D’Aprile \& Talò, 2014; Gallardo \& Sánchez, 2014).

As for the corporate actions that reflect CSR towards customers, Pérez \& Rodríguez del Bosque (2013) highlight that customers especially care about CSR actions that are directly connected to their needs and commercial goals. Thus, previous literature has defended that CSR towards customers basically concerns complete and honest communication of corporate products/services and management of complaints without any discrimination (Pérez et al., 2013), acting in all fairness towards customers (D'Aprile \& Talo, 2014) and being committed to fulfil all corporate obligations (Turker, 2009). For instance, Lee et al. (2016) found information provision to be a key CSR action towards customers, meaning that companies need to provide clear explanations of how their services work (Reverte et al., 2016) with detailed information (El Akremi et al., 2015) and feedback (Rohini \& Madadevappa, 2010). Similarly, Abdullah \& Aziz (2013) identify responsiveness and concern towards customers as key elements within CSR towards customers, which is ascertained through the provision of adequate procedures to deal with customer issues (Alvarado et al., 2017). Scholars have also considered that CSR towards customers includes all actions undertaken to provide the highest quality in products/services and the most competitive prices. This implies analyzing customers' needs and measuring their satisfaction constantly, meeting national and international quality standards (Lee et al., 2016), and taking particular concern in improving the quality of the services offered by the company (Turker, 2009). In this regard, a higher CSR towards customers is seen in terms of a company's ability to provide better products/services while maintaining right quality and prices through utilization of adequate resources and enhanced service levels (Lu et al., 2009). Finally, addressing issues like safety of customers during the use of products and ethical advertising also contribute to the improvement of CSR towards customers. All in all, previous literature defends that corporate relationships with customers should be based on three main facts: information transparency, self-discipline, and the development of new products and services (García de los Salmones et al., 2005). Because the ultimate goal of CSR towards customers is building lasting relationships, CSR should include actions that respect commitment and prioritize customers' satisfaction through the proper identification of customers' needs (Turker, 2009; Kanji \& Chopra, 2010; Pérez et al., 2013).

Nevertheless, previous research on CSR towards customers is scattered and it seems to have failed to provide comprehensive approaches to fully understand the several dimensions that are embedded within this construct. Thus, and based on an extensive review of previous literature that has explored CSR from a customer perspective, the authors of the present paper propose a five-dimensional structure of CSR actions towards customers based on their own classification of the approaches existing in literature. Table 1 shows the dimensions that compose CSR towards customers along with its conceptualization from the customer perspective. The conceptualization and content of the five dimensions is discussed next. 
Table 1. A five-dimensional structure of CSR towards customers

\begin{tabular}{|c|c|c|}
\hline Dimensions & Definitions & Sources \\
\hline $\begin{array}{l}\text { Developmental } \\
\text { responsibilities }\end{array}$ & $\begin{array}{l}\text { Actions oriented towards the enhancement } \\
\text { of products/services through investment in } \\
\text { innovation, utilizing customer satisfaction, } \\
\text { offering quality products/services, and } \\
\text { meeting standards required in the industry. }\end{array}$ & $\begin{array}{l}\text { Skudiene \& Auruskeviciene (2012), } \\
\text { Pérez et al., (2013), Turker (2009), Lu } \\
\text { et al. (2009), El Akremi et al. (2015), } \\
\text { Lee et al. (2016) }\end{array}$ \\
\hline Ethical responsibilities & $\begin{array}{l}\text { A company's ability to act with fairness, } \\
\text { fulfilling obligations through the provision } \\
\text { of equitable products/services, and having } \\
\text { comprehensive codes of conduct that include } \\
\text { customer concerns. }\end{array}$ & $\begin{array}{l}\text { D’Aprile \& Talò (2014), El Akremi et } \\
\text { al., (2015), Turker (2009), Pérez et al., } \\
\text { (2013), Reverte et al. (2016) }\end{array}$ \\
\hline $\begin{array}{l}\text { Relationship-building } \\
\text { responsibilities }\end{array}$ & $\begin{array}{l}\text { Actions towards building more cohesive and } \\
\text { long-lasting relationships with customers by } \\
\text { researching and knowing their needs. }\end{array}$ & $\begin{array}{l}\text { Kanji \& Chopra (2010), Turker (2009), } \\
\text { El Akremi et al., (2015), D’Aprile \& } \\
\text { Talò (2014), Pérez et al. (2013), Fatma } \\
\text { et al. (2014) }\end{array}$ \\
\hline Responsiveness & $\begin{array}{l}\text { Willingness to solve customer problems and } \\
\text { be prompt in the provision of } \\
\text { products/services. }\end{array}$ & $\begin{array}{l}\text { Abdullah \& Aziz (2013), Rohini \& } \\
\text { Mahadevappa (2010), Yeh (2015), } \\
\text { D’Aprile \& Talò (2014), Alvarado et al. } \\
\text { (2017) }\end{array}$ \\
\hline $\begin{array}{l}\text { Information-sharing } \\
\text { responsibilities }\end{array}$ & $\begin{array}{l}\text { Extent to which the company is open to } \\
\text { provide transparent information that is clear, } \\
\text { timely, helpful, detailed and up-to-date. }\end{array}$ & $\begin{array}{l}\text { Reverte et al. (2016), Lee et al. (2016), } \\
\text { El Akremi et al., (2015), Rohini \& } \\
\text { Mahadevappa (2010), D’Aprile \& Talò } \\
\text { (2014) }\end{array}$ \\
\hline
\end{tabular}

Source: Compiled by the authors

Developmental responsibilities. First, previous scholars have frequently focused on issues such as the offering of high quality products and services, use of resources and talent, meeting of international standards, measurement of customer satisfaction to improve services and corporate investment in innovation and provision of broader customer services. All these issues refer to developmental responsibilities of companies, which can be defined as initiatives towards enhancement in service through investment in innovation, utilizing customer satisfaction, offering quality services, and meeting required standards (Turker, 2009; Skudiene \& Auruskeviciene, 2012; Pérez et al., 2013; Lee et al., 2016). This dimension is critical for most companies as they require to continuously enhance and make their products/services more productive in order to retain and enlarge their customer base. In this regard, it is important to note that companies that continuously improve through processes of innovation and development in products/services are clearly oriented towards growth (Reverte et al., 2016). Thus, companies should continuously improve their processes to differentiate their products/services and achieve sustained competitiveness in the long run. Failure to focus on continuous improvement would mean significant loss of competitive advantage and deterioration in the delivery of services due to lack of differentiation in the organization's output for its customers (Damanpour, Walker, \& Avellaneda, 2009).

Ethical responsibilities. Second, for CSR actions to be successful companies also need to satisfy their customers' needs in an ethical way (Carroll, 1991; García de los Salmones et al., 2005; Abdullah \& Aziz, 2013). García de los Salmones et al. (2005) noted that a company whose behavior is perceived to be ethically correct transmits trust to customers and influences their evaluation of the overall quality of the service received. Furthermore, a company that gives priority to its ethical responsibilities can create brand differentiation. Thus, this dimension evaluates whether the company adequately fulfils its ethical and moral responsibilities towards customers 
by including indicators that measure its fairness, ethical principles and codes of conduct, fulfillment of obligations and equity of services. Along this line, Wood (2010) argued that moral responsibility is primary for all human institutions, in short, businesses are free to make money only after they had complied with ethical requirements. Otherwise, there would be no reason to mention businesses' social legitimacy.

Relationship-building responsibilities. Building high quality relationships with customers holds significant importance for companies. In this regard, companies that strive to develop longterm relationships with customers and satisfy their various needs and desires are in a better position to increase loyalty. On the contrary, neglecting this corporate responsibility presents great risks if competitors are able to improve the quality and value of their relationship with customers and, thus, they achieve loyalty first (Yeh, 2015). This relationship-building dimension refers to corporate actions oriented towards building more cohesive and long-lasting relationships with customers, primarily achieved by researching and better knowing customer needs (Kanji \& Chopra, 2010; Pérez et al., 2013; D’Aprile \& Talò, 2014). Thus, relationship-building responsibilities reflect the company's commitment to customers, which is shown by giving them high priority (Turker, 2009), providing accessible services (El Akremi et al., 2015), monitoring customer needs (Pérez \& Rodríguez del Bosque, 2013) and implementing actions to reward and improve customer loyalty (D'Aprile \& Talo, 2014).

Responsiveness. Scholars have demonstrated that companies also need to associate their CSR actions with an image of responsiveness to the needs of the customers on which they depend for continued survival (Marín et al., 2009). Thus, previous literature has proposed to explore a fourth type of CSR actions that reflect whether companies are responsive towards their customers or not. In this regards, responsiveness refers to the willingness of the company to solve customer problems and be prompt in providing products/services (Abdullah \& Aziz, 2013; Yeh, 2015). Responsiveness implies showing concern for customers (Abdullah \& Aziz, 2013), showing a positive attitude towards them (D'Aprile \& Talò, 2014), being responsive to complaints (Abdullah $\&$ Aziz, 2013) and having formal procedures to attend and respond those complaints (Alvarado et al., 2017).

Information-sharing responsibilities. This dimension measures the extent to which companies meet the information provision responsibilities they have towards their customers (D’Aprile \& Talò, 2014; Lee et al., 2016). Along this line, companies that subject themselves to the provision of information to their customers are considered socially responsible and, as so, they can easily build trust among their customers (Pivato et al., 2008). Thus, information sharing holds significance since it can help improve credibility among customers, leading to favorable attitude towards the company, and predisposing customers to pass on the information to others and to recommend the company to other prospective customers (Eberle et al., 2013). Furthermore, corporate performance has also been found to significantly correlate with this dimension of the CSR towards customers (Homburg et al., 1999).

\section{Measuring customer perceptions of CSR}

As for the measurement of CSR, a variety of measurement methodologies can be found in academic literature (D'Aprile \& Talo, 2014). Maignan \& Ferrell (2000) categorized the existing alternative methods into three main approaches: (a) expert assessments, (b) single/multiple 
indicators and (c) surveys. Additionally, Turker (2009) classified these methods into five categories, including databases or reputation indices, single/multiple indicators, content analysis of publications, and scales measuring CSR at the individual and/or corporate level. Nevertheless, most of these methods are used to measure the CSR performance of companies objectively based on information provided either by the companies themselves or industry and society experts. On the contrary, the focus of the present research is on the measurement of customer perceptions of CSR, which are most frequently assessed through the use of scales included in research surveys collected among customers directly. As explained by Martínez et al. (2013), surveys are the most appropriate method to evaluate customer perceptions because the other approaches require that customers have access to CSR information that might be too difficult to acquire and store (Mohr et al., 2001).

Nevertheless, the review of previous scales proposed in literature to measure CSR perceptions reveals that much of the existing literature has focused on stakeholders inside the company, such as managers (Maignan \& Ferrell, 2000; Valentine \& Fleischman, 2008) or employees (Ellen et al., 2006; Lu et al., 2009). Some researchers have also based their CSR scales on external stakeholders such as business and society experts (Singhapakdi et al., 1995), social activists (Starrett, 1996), students (Brown \& Dacin, 1997), residents (Webb et al., 2007) or exporters (Boehe \& Cruz, 2010). Nonetheless, the assessment of customer perceptions has received little attention so far (Öberseder et al., 2014; Alvarado et al., 2017). Concerning this issue, Table 2 presents a summary of the most significant measurement scales that have been proposed in literature to evaluate CSR perceptions among different stakeholders. As it is shown in this table, out of the 44 measurement scales that were explored for this paper, only 8 were developed to measure customer perceptions. These scales were proposed by Lichtenstein et al. (2004), García de los Salmones et al. (2005), Pérez \& Rodríguez del Bosque (2013), Pérez et al. (2013), Rodrígues \& Borges (2015), Yeh (2015), Kim \& Ferguson (2016) and Alvarado et al. (2017).

Nonetheless, customers' expectations and opinions are considered to directly influence the design and effectiveness of corporate actions and as so their study is essential in the academic and business fields (Fukukawa et al., 2007). In this regard, scholars have demonstrated that it is important that companies spend the resources allocated to CSR in ways that yield optimum benefits to society as well as to their stakeholders, especially customers. When buying, customers take into account their perceptions of ethical or unethical actions carried out by companies. Accordingly, customers push companies to behave ethically since they are prepared to punish companies when they see them falling below the standards expected (Marín \& Ruiz, 2007). On the contrary, when engaging in CSR that is congruent with customer preferences companies tend to increase their potential to gain positive attitudes among them.

Table 2. Summary of survey scales to measure perceptions of CSR

\begin{tabular}{lll}
\hline Author(s) & Research settings & Respondents \\
\hline Singhapakdi et al. (1995) & American Marketing Association (AMA) & Marketing experts \\
\hline Starrett (1996) & Not reported & Social activists \\
\hline Singhapakdi et al. (1996) & US business schools & Students \\
\hline Brown \& Dacin (1997) & University & Students \\
\hline Maignan \& Ferrell (2000) & United States and France & Managers \\
\hline Quazi \& O'Brien (2000) & $\begin{array}{l}\text { Food and textile industries in Australia } \\
\text { and Bangladesh }\end{array}$ & Managers \\
\hline
\end{tabular}




\section{Davenport (2000)}

\begin{tabular}{|c|c|c|}
\hline Sen \& Bhattacharya (2001) & Business students & Students \\
\hline Lichtenstein et al. (2004) & $\begin{array}{l}\text { Study 1: National Food Chain } \\
\text { Study 2: Marketing Courses }\end{array}$ & Customers \\
\hline García de los Salmones et al. (2005) & Telecom industry & Customers \\
\hline David et al. (2005) & Large Midwestern American university & Students \\
\hline Ellen et al. (2006) & University & Employees \\
\hline Sen et al. (2006) & Business and engineering schools & Students \\
\hline Webb et al. (2007) & American households & Residents \\
\hline Valentine \& Fleischman (2008) & Business companies & Managers \\
\hline Dzansi \& Pretorius (2009) & Small businesses in South Africa & Owners / managers \\
\hline Lu et al. (2009) & $\begin{array}{l}\text { Container shipping companies and } \\
\text { agencies }\end{array}$ & Employees \\
\hline Turker (2009) & Turkish businesses & Business professionals \\
\hline Rohini \& Mahadevappa (2010) & Hospitals & Employees \\
\hline Boehe \& Cruz (2010) & Brazilian export companies & Exporters \\
\hline Kanji \& Chopra (2010) & Not reported & Not reported \\
\hline Chow \& Chen (2012) & China & Managers \\
\hline Skudiene \& Auruskeviciene (2012) & Lithuanian companies & Employees \\
\hline Pérez \& Rodríguez del Bosque (2013) & Banking industry & Customers \\
\hline Pérez et al. (2013) & Banking industry & Customers \\
\hline Lee \& Kim (2013) & Tourism industry & Employees \\
\hline Abdullah \& Aziz (2013) & University & Students \\
\hline Martínez et al. (2013) & Spanish tourism industry & Residents \\
\hline Gallardo \& Sánchez (2014) & $\begin{array}{l}\text { Medium and big companies within a } \\
\text { specific regional context }\end{array}$ & Managers \\
\hline D’Aprile \& Talò (2014) & $\begin{array}{l}\text { Business professionals working in } \\
\text { Southern Italian SME's }\end{array}$ & Employers / Employees \\
\hline Fatma et al. (2014) & Banking Industry & Employees \\
\hline Glavas \& Kelley (2014) & Food and agriculture industry & Employees \\
\hline Rodrigues \& Borges (2015) & Portuguese apparel brand & Customers \\
\hline Yeh $(2015)$ & Wealth management service providers & Customers \\
\hline El Akremi et al. (2015) & Construction industry & Employees \\
\hline Taghian et al. (2015) & Australian businesses & Employees \\
\hline Kim \& Ferguson (2016) & United Sates & Customers \\
\hline Reverte et al. (2016) & Eco-responsible Spanish companies & Managers \\
\hline Mehralian et al. (2016) & Iranian pharmaceutical industry & Managers \\
\hline Mory et al. (2016) & International pharmaceutical company & Employees \\
\hline Quazi et al. (2016) & Not reported & Students \\
\hline Lee et al. (2016) & Communications Industry & Experts \\
\hline Alvarado et al. (2017) & $\begin{array}{l}24 \text { countries in two different cultural and } \\
\text { geographical contexts }\end{array}$ & Customers \\
\hline
\end{tabular}

Source: Compiled by the authors
Conceptual paper that proposes principles for CSP categorized into Ethical Business Behavior, Stakeholder Commitment, and Environmental Commitment

On the one hand, one of the scales in this review propose a one-dimensional tool to measure customer perceptions of CSR. In this regard, an early attempt to measure customer perceptions of CSR came from Lichtenstein et al. (2004), who proposed a scale exclusively focused on the charitable giving and philanthropic responsibilities of the company. Nonetheless, this scale only covers a single aspect of customer perceptions of CSR, while this has been recognized as a multi- 
dimensional construct (El Akremi et al., 2015). As highlighted by Keeble et al. (2003), it is important to note that the definition of a single indicator is a very restrictive way of measuring a construct (Keeble et al., 2003).

On the other hand, several multidimensional tools have also been proposed to measure customer perceptions of CSR. For instance, García de los Salmones et al. (2005) tested a scale to measure customer perceptions of the CSR actions undertaken by telecom companies based on Carroll's pyramid of corporate responsibilities (i.e., economic, legal, ethical and philanthropic responsibilities). Their findings revealed that only three dimensions (legal, ethical and philanthropic responsibilities) were relevant for customers when evaluating CSR actions. However, this scale has been criticized for its lack of reflection of issues pertinent to customers because it focused on broad CSR issues such as the respect and protection of the natural environment, donations to social projects or improvement in the general well-being of society (Alvarado et al., 2017). Along this line, it is noticeable that many of the statements in all the previous scales that were reviewed in this research are pertinent to broad CSR dimensions, while they significantly lack a clearer focus on the responsibilities of companies towards customers themselves. For instance, statements referring to how the company 'directs part of its budget to donations and social works favoring the disadvantaged' (García de los Salmones et al., 2005) or 'tries to recycle its waste materials properly' (Alvarado et al., 2017) are too broad and require significant knowledge on the part of customers to give proper answers when fulfilling the questionnaires and scales.

Along this line, Pérez \& Rodríguez del Bosque (2013) identified corporate responsibilities towards customers, shareholders \& supervising boards, employees and society as the four key dimensions of customer perceptions of CSR. However, a significant limitation of the scale is observed in the fact that asking customers about the responsibility of companies towards other stakeholders (e.g., employees or supervising boards) can limit the reliability and validity of customer responses because they may lack adequate knowledge about the CSR actions implemented by companies in these fields. This limitation pertinent to the content validity of this measurement tool has also been identified in other multidimensional scales. For instance, the scales proposed by Öberseder et al. (2014) and Alvarado et al. (2017) also assume that customers must have a certain degree of knowledge of the company's CSR actions to prevent erratic, unthinking responses or reactions that are marked by social desirability. However, in real business contexts there is usually low awareness of a company's CSR actions among its external stakeholders, especially customers (Pomering \& Dolnicar, 2009). Thus, customers may encounter comprehension problems when responding to this type of measurement scales.

All in all, and given that perceptions of CSR do influence customer responses towards companies (Pérez \& Rodríguez del Bosque, 2013), this literature review of previous scales suggest that further research is needed to improve the measurement of customer perceptions of the CSR actions implemented by companies to improve their satisfaction. In the present paper, the authors propose a scale that only collects issues that are closely linked to CSR towards customers in an attempt to overcome the limitations identified in previous scales and include dimensions and items about which customers may have better knowledge, thus facilitating their input and clearly 
highlighting customers' perceptions about the CSR actions towards customers undertaken by companies. Actually, some of the scholars previously discussed in this section have asked for further research to identify additional dimensions that could affect customer perceptions of CSR (Pérez \& Rodríguez del Bosque, 2013; Öberseder et al., 2014). Hence, to obtain a deeper understanding of CSR from a customer perspective, in this paper a new scale is proposed that only focuses on customer perceptions of the five dimensions of CSR towards customers that have been previously described in this paper (i.e., developmental, ethical, relationship-building, responsiveness and information-sharing responsibilities).

\section{Method and findings}

\section{Research setting: Telecom industry in Pakistan}

CSR is now widely acknowledged as an important strategic consideration for companies across all industries and telecom companies are not exception. The global telecommunications industry has annual revenues exceeding US\$2 trillion, a $4.3 \%$ growth path over the last five years (the fastest growth occurring in emerging markets) and it involves more than one million companies worldwide (IBISWorld, 2017). Thus, the study of the telecom industry is considerably interesting due to its recent growth and innovation that specially happens in developing countries such as the one that is explored in this research (i.e., Pakistan). However, CSR literature in this industry is underdeveloped even though it is generally agreed that telecom companies produce substantial social impacts (e.g. related to the short life cycles of equipment and the 'digital divide'). Nevertheless, some scholars have found that CSR has impacts on corporate performance in the telecom industry. Thus, exploring customer perceptions of CSR in this setting is especially interesting for research and it will allow the authors to provide new useful implications for the advancement of CSR in this industry.

\section{Scale development and validation}

The procedure used in this study to develop a measure for customer perceptions of CSR follow the generally accepted principles of instrument design (Churchill, 1979). More precisely, the procedure follows seven steps: (1) identification of the domain of the construct; (2) item generation through existing literature; (3) categorization of items into each dimension of the construct; (4) pilot study and purification, including expert validation and scale modification, refinement and finalization; (5) data collection; (6) exploratory factor analysis (EFA) to identify the underlying dimensions of the scale (using IBM SPSS 20) and (7) confirmatory factor analysis (CFA) to test reliability and validity of the proposed scale (using SMART-PLS 3.0).

\section{Step 1 - Domain of the construct}

As previously explained in the literature review sections, the domain of the construct tested in this paper is CSR analyzed from a customer perspective. More precisely, the proposed scale is aimed at measuring customer perceptions of CSR, specifically the CSR actions implemented by companies to improve customer satisfaction. 
In order to generate the scale items, research has highlighted a number of different procedures, such as literature review, expert surveys or group discussions (Churchill, 1979; Turker, 2009), among others. For greater rigor, the present study involved a combination of several of these methods. Initially, a total of 47 items were drafted based on the review of existing literature and with the focus on CSR statements that could be linked to customers. Once the items that could potentially measure CSR towards customers were identified, the authors categorized the original statements into the five dimensions of CSR towards customers theoretically conceptualized in the paper. Furthermore, the study involved discussions with academics and professionals for validation of the items that could efficiently and effectively measure customer perceptions of CSR. Thus, and in order to further purify the items, the scale was presented to (1) the Head of the Management Sciences Department at the University X (country X) and (2) three full professors and researchers specialized in the fields of CSR and management sciences in the same university. The panel was asked to critically analyze each of the items in respect to the dimension it was supposed to measure. The panel was also asked to assess if the dimensions could adequately represent the measurement of CSR towards customers. This approach has already been used in previous literature to develop social responsibility scales successfully (Latif, 2017). The process resulted in several items being eliminated from the scale and several items being reformulated for a better understanding. Upon completion of this step, a total of 33 items were finally included in the scale. All the items and the sources from where they were chosen are shown in Table 3 . In the survey that was distributed among customers afterwards, each statement was preceded by the introductory words "I think that the company...".

Table 3. Initial set of items

\begin{tabular}{|c|c|c|}
\hline Dimensions & Items (This company...) & Sources \\
\hline \multirow{7}{*}{$\begin{array}{l}\text { Developmental } \\
\text { responsibilities }\end{array}$} & $\begin{array}{l}\text { DE1. Invests in innovations which provide advantage to the } \\
\text { customers }\end{array}$ & $\begin{array}{l}\text { Skudiene \& } \\
\text { Auruskeviciene (2012) }\end{array}$ \\
\hline & $\begin{array}{l}\text { DE2. Uses customers' satisfaction as an indicator to improve } \\
\text { the services }\end{array}$ & Pérez et al. (2013) \\
\hline & $\begin{array}{l}\text { DE3. Takes particular concern to offer high quality services to } \\
\text { its customers }\end{array}$ & Turker (2009) \\
\hline & $\begin{array}{l}\text { DE4. Uses its resources and talent for its own growth to } \\
\text { ensure better service }\end{array}$ & Lu et al. (2009) \\
\hline & $\begin{array}{l}\text { DE5. Services satisfy national and international quality } \\
\text { standards (i.e., ISO standards) }\end{array}$ & Lee et al. (2016) \\
\hline & $\begin{array}{l}\text { DE6. Guarantee that its services are broader as compared to its } \\
\text { competitors }\end{array}$ & El Akremi et al. (2015) \\
\hline & $\begin{array}{l}\text { DE7. Is trying to continuously improve the quality of the } \\
\text { services that it offers }\end{array}$ & Lee et al. (2016) \\
\hline \multirow{6}{*}{ Ethical responsibilities } & $\begin{array}{l}\text { ET1. Believes that fairness toward customers is an integral } \\
\text { part of the business }\end{array}$ & D’Aprile \& Talò (2014) \\
\hline & ET2. Is committed to well-established ethical principles & El Akremi et al. (2015) \\
\hline & $\begin{array}{l}\text { ET3. Is concerned to fulfil its obligations towards its } \\
\text { customers }\end{array}$ & Turker (2009) \\
\hline & $\begin{array}{l}\text { ET4. Does not discriminate on any basis and offers equal } \\
\text { quality of service to all customers }\end{array}$ & Pérez et al. (2013) \\
\hline & ET5. Has a comprehensive code of conduct & Reverte et al. (2016) \\
\hline & RB1. Respects its commitments to customers & Kanji \& Chopra (2010) \\
\hline
\end{tabular}




\begin{tabular}{|c|c|c|}
\hline \multirow{6}{*}{$\begin{array}{l}\text { Relationship-building } \\
\text { responsibilities }\end{array}$} & & \multirow{3}{*}{$\begin{array}{l}\text { Turker (2009) } \\
\text { El Akremi et al. (2015) }\end{array}$} \\
\hline & RB2. Gives high priority to customer satisfaction & \\
\hline & $\begin{array}{l}\text { RB3. Ensures that its services are accessible for all its } \\
\text { customers }\end{array}$ & \\
\hline & RB4. Makes an effort to increase the level of customer loyalty & D'Aprile \& Talò (2014) \\
\hline & RB5. Makes an effort to know customer needs & Pérez et al. (2013) \\
\hline & RB6. Treats its customer honestly & Fatma et al. (2014) \\
\hline \multirow{6}{*}{ Responsiveness } & RE1. Is responsive to the complaints of its customers & Abdullah \& Aziz (2013) \\
\hline & RE2. Shows concern towards the customers interest & Abdullah \& Aziz (2013) \\
\hline & $\begin{array}{l}\text { RE3. Establishes procedures to comply with customer } \\
\text { complaints }\end{array}$ & $\begin{array}{l}\text { Rohini \& Mahadevappa } \\
\text { (2010) }\end{array}$ \\
\hline & RE4. Registers and resolves complaints in a timely manner & Yeh $(2015)$ \\
\hline & $\begin{array}{l}\text { RE5. Shows a positive attitude and responsible behavior } \\
\text { towards customers }\end{array}$ & D’Aprile \& Talò (2014) \\
\hline & $\begin{array}{l}\text { RE6. Has formal procedures for interaction and dialogue with } \\
\text { customers }\end{array}$ & Alvarado et al. (2017) \\
\hline \multirow{9}{*}{$\begin{array}{l}\text { Information-sharing } \\
\text { responsibilities }\end{array}$} & IS1. Clearly explains the way the service works & Reverte et al. (2016) \\
\hline & IS2. Offers clear, precise, and required information & Lee et al. (2016) \\
\hline & IS3. Is helpful to customers and advises them about its services & Lee et al. (2016) \\
\hline & IS4. Offers up-to-date information & Lee et al. (2016) \\
\hline & IS5. Offers useful information & Lee et al. (2016) \\
\hline & IS6. Offers easy access to information & Lee et al. (2016) \\
\hline & IS7. Offers detailed information related to the new offers & El Akremi et al. (2015) \\
\hline & IS8. Responds well to customer feedback & $\begin{array}{l}\text { Rohini \& Mahadevappa } \\
\text { (2010) }\end{array}$ \\
\hline & IS9. Gives information to customers immediately & D’Aprile \& Talò (2014) \\
\hline
\end{tabular}

After the generation of the initial set of items, data was collected for a pilot study. A total of 33 respondents participated in the study. A draft questionnaire was proposed. The draft questionnaire was divided in two parts. Part A comprised respondents' demographic and academic backgrounds. In part B, respondents were asked to rate their level of agreement with each of the 33 statements defined in steps 2 and 3 on a 5-point Likert-type scale ( 1 = "strongly disagree"; $5=$ "strongly agree"). Respondents were also asked to provide any comments pertinent to the statements for further improvement and clarity. Afterwards, the survey was submitted to a native English-speaking editor and 5 new academics for their feedback. The expert editor commented on the omissions/errors and perceived ambiguities pertinent to the questionnaire. Consequently, modifications were made to the draft questionnaire according to the suggestions made by the pilot sample, the style editor and the academics that revised the scale at this research stage.

\section{Step 5 - Data collection}

Using a convenience-sampling technique, data was collected from customers of different telecom companies operating in Pakistan, who were contacted personally (i.e., personal interviews) and electronically (i.e., online surveys). After collection and refinement of the database, a total of 393 questionnaires were found complete and usable. A summary of the respondents' profile is presented in Table 4. 
Table 4. Respondents' profile

\begin{tabular}{lcc}
\hline Demographic variables & Frequency & Percentage \\
\hline Age & & \\
$20-29$ & 118 & 30.03 \\
$30-39$ & 156 & 39.69 \\
$40-49$ & 73 & 18.58 \\
50 or Over & 46 & 11.70 \\
\hline Gender & & \\
Male & 191 & 48.60 \\
Female & 202 & 51.40 \\
\hline Occupation & & \\
Student & 121 & 30.79 \\
Self-Employed & 119 & 30.28 \\
Worker at a Company & 116 & 29.52 \\
Retired & 37 & 9.41 \\
\hline
\end{tabular}

Step 6 - Exploratory Factor Analysis (EFA)

After data collection and refinement, the authors started the evaluation of the scale structure and its psychometric properties to determine the reliability and validity of the multidimensional tool proposed to measure customer perceptions of CSR. As a first step in this procedure, an exploratory factor analysis (EFA) was performed using a principal component analysis and varimax rotation with the statistical software IBM SPSS 20. In this regard, EFA has been utilized in a number of CSR scale development studies as a first step to verify the dimensional structure of the scales (Turker, 2009, Martínez et al., 2013; Fatma et al., 2014; El Akremi et al., 2015). The minimum factor loading criteria was set to .500 . The communality of the scale, which indicates the amount of variance in each dimension, was also assessed to ensure acceptable levels of explanation. The results show that all communalities were over .500 except for one, "ET5. (The company) has a comprehensive code of conduct" (.485). However, the item, which was close to the .500 margin, was retained for further analysis to assure the content validity of the scale.

EFA requires a number of assumptions to be met. First, a critical assumption is to test whether the data matrix has sufficient correlations. A visual examination of the correlation matrix revealed that almost all the correlations were significant at $\mathrm{p}<.001$, thus providing an excellent footing for factor analysis. Following the examination of the correlation matrix, a second step involved weighing the overall significance of the correlation matrix through Bartlett's Test of Sphericity, which provides a measure of the statistical probability that the correlation matrix has significant correlations among some of its components. The results were significant, $\chi 2(n=393)=$ $7392.221(\mathrm{p}<.001)$, which indicates its suitability for factor analysis. The Kaiser-Meyer-Olkin Measure of Sampling Adequacy (MSA), which indicates the appropriateness of the data for factor analysis, was .958. In this regard, data with MSA values above .800 are considered appropriate for factor analysis. Finally, the factor solution derived from this analysis yielded 5 factors for the scale, which accounted for $58.949 \%$ of the variation in the data.

Nonetheless, in this initial EFA three items (i.e., "DE7. Is trying to continuously improve the quality of the services that it offers", "RB6. Treats its customer honestly" and "RE3. 
Establishes procedures to comply with customer complaints") failed to load on any dimension significantly. Thus, the authors repeated the EFA without including these items. The results of this new analysis confirmed the 5-dimensional structure theoretically defined in the research (Table 5). The Kaiser-Meyer-Olkin MSA was .955. The 5 dimensions explained a total of $60.440 \%$ of the variance among the items in the study. The Bartlett's Test of Sphericity proved to be significant and all communalities were over the required value of .500 . The 5 factors identified as part of this EFA aligned with the theoretical proposition in this research. Factor 1 includes items DE1 to DE6, referring to developmental (DE) responsibilities. Factor 2 gathers items ET1 to ET5, which represent ethical (ET) responsibilities of companies in the telecom industry. Factor 3 includes items RB1 to RB5, referring to relationship-building (RB) responsibilities. Factor 4 refers to corporate responsiveness (RE) towards customers, including items RE1-RE2 and RE4 to RE6. Finally, Factor 5 includes items IS1 to IS9, which represent information-sharing (IS)

13 responsibilities.

Table 5. Results of the exploratory factor analysis (EFA)

\begin{tabular}{|c|c|c|c|c|c|}
\hline Items & DE & ET & RB & RE & IS \\
\hline DE1. Invests in innovations which provide advantage to the customers & .743 & & & & \\
\hline DE2. Uses customers' satisfaction as an indicator to improve the services & .720 & & & & \\
\hline DE3. Takes particular concern to offer high quality services to its customers & .752 & & & & \\
\hline DE4. Uses its resources and talent for its own growth to ensure better service & .561 & & & & \\
\hline DE5. Services satisfy national and international quality standards (i.e., ISO standards) & .574 & & & & \\
\hline DE6. Guarantee that its services are broader as compared to its competitors & .515 & & & & \\
\hline ET1. Believes that fairness toward customers is an integral part of the business & & .548 & & & \\
\hline ET2. Is committed to well-established ethical principles & & 611 & & & \\
\hline ET3. Is concerned to fulfil its obligations towards its customers & & .599 & & & \\
\hline $\begin{array}{l}\text { ET4. Does not discriminate on any basis and offers equal quality of service to all } \\
\text { customers }\end{array}$ & & .539 & & & \\
\hline ET5. Has a comprehensive code of conduct & & 621 & & & \\
\hline RB1. Respects its commitments to customers & & & .506 & & \\
\hline RB2. Gives high priority to customer satisfaction & & & .593 & & \\
\hline RB3. Ensures that its services are accessible for all its customers & & & .707 & & \\
\hline RB4. Makes an effort to increase the level of customer loyalty & & & .701 & & \\
\hline RB5. Makes an effort to know customer needs & & & .551 & & \\
\hline RE1. Is responsive to the complaints of its customers & & & & 685 & \\
\hline RE2. Shows concern towards the customers interest & & & & .583 & \\
\hline RE4. Registers and resolves complaints in a timely manner & & & & .542 & \\
\hline RE5. Shows a positive attitude and responsible behavior towards customers & & & & 519 & \\
\hline RE6. Has formal procedures for interaction and dialogue with customers & & & & 601 & \\
\hline IS1. Clearly explains the way the service works & & & & & .587 \\
\hline IS2. Offers clear, precise, and required information & & & & & .621 \\
\hline IS3. Is helpful to customers and advises them about its services & & & & & .596 \\
\hline IS4. Offers up-to-date information & & & & & .651 \\
\hline IS5. Offers useful information & & & & & 688 \\
\hline IS6. Offers easy access to information & & & & & .666 \\
\hline IS7. Offers detailed information related to the new offers & & & & & .629 \\
\hline IS8. Responds well to customer feedback & & & & & .579 \\
\hline IS9. Gives information to customers immediately & & & & & .594 \\
\hline
\end{tabular}


Step 7 - Assessment of Construct Validity

SMART PLS 3.0 was used to assess reliability, through Cronbach's alpha $(\alpha)$ and composite reliability (CR), and convergent/discriminant validity. Before assessment of reliability and validity, the degree of multicollinearity among the indicators should be assessed by calculating the variance inflation factor (VIF) (Cassel \& Hackl, 2000). The VIF indicates how much of an indicator's variance is explained by the other indicators of the same construct. Values below the commonly accepted threshold of 10 indicate that multicollinearity is not an issue (Diamantopoulos $\&$ Siguaw, 2006). The results are summarized in Tables 6 and 7.

Table 6. Reliability and Convergent Validity Assessment

\begin{tabular}{|c|c|c|c|c|c|c|}
\hline Dimensions & Items & $\lambda$ & $\alpha$ & $\mathbf{C R}$ & AVE & VIF \\
\hline \multirow{6}{*}{ Developmental responsibilities } & DE1 & .801 & \multirow{6}{*}{.862} & \multirow{6}{*}{.897} & \multirow{6}{*}{.593} & 2.226 \\
\hline & DE2 & .804 & & & & 2.166 \\
\hline & DE3 & .827 & & & & 2.183 \\
\hline & DE4 & .741 & & & & 1.654 \\
\hline & DE5 & .725 & & & & 1.638 \\
\hline & DE6 & .716 & & & & 1.546 \\
\hline \multirow{5}{*}{ Ethical responsibilities } & ET1 & .734 & \multirow{5}{*}{.797} & \multirow{5}{*}{.860} & \multirow{5}{*}{.553} & 1.578 \\
\hline & ET2 & .753 & & & & 1.697 \\
\hline & ET3 & .811 & & & & 1.811 \\
\hline & ET4 & .738 & & & & 1.61 \\
\hline & ET5 & .676 & & & & 1.431 \\
\hline \multirow{5}{*}{ Relationship-building responsibilities } & RB1 & .730 & \multirow{5}{*}{.833} & \multirow{5}{*}{.882} & \multirow{5}{*}{.600} & 1.542 \\
\hline & RB2 & .814 & & & & 1.915 \\
\hline & RB3 & .782 & & & & 1.784 \\
\hline & RB4 & .804 & & & & 1.93 \\
\hline & RB5 & .740 & & & & 1.639 \\
\hline \multirow{5}{*}{ Responsiveness } & RE1 & .726 & \multirow{5}{*}{.843} & \multirow{5}{*}{.888} & \multirow{5}{*}{.615} & 2.039 \\
\hline & RE2 & .820 & & & & 1.945 \\
\hline & RE4 & .812 & & & & 1.917 \\
\hline & RE5 & .771 & & & & 1.852 \\
\hline & RE6 & .787 & & & & 1.631 \\
\hline \multirow{9}{*}{ Information-sharing responsibilities } & IS1 & .724 & \multirow{9}{*}{.905} & \multirow{9}{*}{.922} & \multirow{9}{*}{.568} & 1.886 \\
\hline & IS2 & .785 & & & & 2.263 \\
\hline & IS3 & .774 & & & & 2.29 \\
\hline & IS4 & .786 & & & & 2.408 \\
\hline & IS5 & .770 & & & & 2.314 \\
\hline & IS6 & .771 & & & & 2.143 \\
\hline & IS7 & .712 & & & & 1.713 \\
\hline & IS8 & .732 & & & & 1.866 \\
\hline & IS9 & .726 & & & & 2.044 \\
\hline
\end{tabular}


As far as reliability is concerned, all $\alpha$ were above the minimum recommended value of .700 and all values of CR were between .876 and .943 , showing that measures in the study were reliable. In order to assess convergent validity, the authors evaluated the Average Variance Extracted (AVE) statistics of each dimension. An AVE value of .500 or higher establishes convergent validity. Because the AVE values for each of the dimensions of customer perceptions of CSR were over .500, convergent validity was confirmed. Furthermore, there was moderate to high correlation among all the 5 dimensions of the scale (Table 7), also indicating evidence of convergent validity. Discriminant validity is established if the constructs'/dimensions' AVEs are greater than the squared inter-correlations of other constructs/dimensions. In this study, the results of the analysis show that the AVEs were greater than the squared correlation between each pair of dimensions (Table 7), thus providing evidence for discriminant validity.

Table 7. Square inter-correlations among dimensions and discriminant validity*

\begin{tabular}{|c|c|c|c|c|c|}
\hline & 1 & 2 & 3 & 4 & 5 \\
\hline Developmental responsibilities (1) & .770 & & & & \\
\hline Ethical responsibilities (2) & 683 & .744 & & & \\
\hline Relationship-building responsibilities (3) & 671 & .666 & .775 & & \\
\hline Responsiveness (4) & 672 & .670 & .684 & .784 & \\
\hline Information-sharing responsibilities (5) & 681 & .698 & .738 & .753 & .754 \\
\hline
\end{tabular}

Finally, the authors also evaluated the model by examining the factor loadings of each item on each dimension of the scale, which provides another way to assess convergent and discriminant validity (Wasko \& Faraj, 2005). In order to assure validity, the factor loading of an item on its dimension should always be greater than its loading on any other dimension of the scale (Wasko $\&$ Faraj, 2005). Based on this analysis, once again sufficient convergent and discriminant validity is demonstrated (Table 8).

Table 8. Factor loadings on each dimension of the scale

\begin{tabular}{lccccc}
\hline & $\begin{array}{c}\text { Developmental } \\
\text { responsibilities }\end{array}$ & $\begin{array}{c}\text { Ethical } \\
\text { responsibilities }\end{array}$ & $\begin{array}{c}\text { Relationship-building } \\
\text { responsibilities }\end{array}$ & Responsiveness & $\begin{array}{c}\text { Information-sharing } \\
\text { responsibilities }\end{array}$ \\
\hline DE1 & .801 & .493 & .500 & .530 & .489 \\
DE2 & .804 & .541 & .495 & .561 & .519 \\
DE3 & .827 & .557 & .548 & .542 & .559 \\
DE4 & .741 & .558 & .525 & .498 & .526 \\
DE5 & .725 & .492 & .485 & .475 & .523 \\
DE6 & .716 & .512 & .545 & .492 & .529 \\
\hline ET1 & .543 & .734 & .491 & .499 & .524 \\
ET2 & .491 & .753 & .473 & .527 & .471 \\
ET3 & .578 & .811 & .524 & .554 & .571 \\
ET4 & .493 & .738 & .537 & .487 & .540 \\
ET5 & .423 & .676 & .446 & .417 & .484 \\
\hline RB1 & .511 & .533 & .730 & .547 & .556 \\
RB2 & .589 & .565 & .814 & .548 & .597 \\
RB3 & .470 & .504 & .782 & .481 & .581
\end{tabular}




\begin{tabular}{llllll} 
RB4 & .527 & .494 & .804 & .563 & .541 \\
RB5 & .495 & .479 & .740 & .509 & .580 \\
\hline RE1 & .500 & .551 & .534 & .820 & .561 \\
RE2 & .576 & .572 & .588 & .812 & .606 \\
RE4 & .529 & .464 & .479 & .771 & .575 \\
RE5 & .561 & .503 & .536 & .787 & .659 \\
RE6 & .459 & .536 & .541 & .726 & .545 \\
\hline IS1 & .465 & .520 & .535 & .550 & .724 \\
IS2 & .514 & .564 & .585 & .574 & .785 \\
IS3 & .537 & .530 & .619 & .583 & .774 \\
IS4 & .517 & .497 & .589 & .607 & .776 \\
IS5 & .510 & .542 & .537 & .513 & .771 \\
IS6 & .496 & .527 & .554 & .546 & .712 \\
IS7 & .485 & .478 & .482 & .554 & .732 \\
IS8 & .548 & .554 & .580 & .620 & .726 \\
IS9 & .542 & .523 & .511 & .561 & \\
\hline
\end{tabular}

\section{Discussion and conclusions}

A detailed review of academic literature shows that the identification of rigorous and complete measures of customer perceptions of CSR is a complicated task (Carroll, 2000). This research venue is relatively new and there are still few studies testing reliable scales to measure CSR from a customer's point of view. In this regard, the existing literature presents several studies that provide a number of different measures that identify the critical dimensions of CSR mostly from the perspective of internal stakeholders (e.g. employees). However, there has been significantly limited research on the customer's perception of CSR. In addition to this idea, the literature review has also shown that most of the previous studies that present scales to measure customer perceptions propose tools that are either too narrow or too broad to allow us understanding the responsibilities of companies towards their customers correctly, even though this is one of the most critical stakeholders for the economic purposes of businesses. Based on these limitations, in this paper the authors have designed a new tool to measure customer perceptions of the CSR oriented towards customers that is implemented in the telecom industry in Pakistan, and they have tested its reliability and validity through diverse statistical techniques.

The most outstanding result of this study is the confirmation of the multidimensional nature of CSR towards customers, which is consistent with the findings of previous research (Boehe \& Cruz, 2010; Skudiene \& Auruskeviciene, 2012; Abdullah \& Aziz, 2013; D’Aprile \& Talò, 2014; Reverte et al., 2016). In this regard, a total of five dimensions were theoretically identified and empirically tested as part of customers' perceptions of CSR. These dimensions include developmental, ethical, relationship-building, responsiveness and information-sharing responsibilities.

First, developmental responsibilities measure corporate actions mostly related to the enhancement in products and services through investment in innovation, evaluation of customer satisfaction and adherence to industry standards. This dimension is critical for companies as they 
require to continuously improve, enhance, and make their products/services more productive in order to retain and further increase their customer base. In this regard, research has identified corporate CSR as a viable and productive means of increasing customer satisfaction, while CSR investments also lead to higher levels of corporate credibility (Sun \& Price, 2016).

Ethical responsibilities measure whether the company has been fulfilling its moral responsibilities when dealing with customers. Ethical responsibilities have been identified as key ingredients of CSR in previous studies (Carroll, 1991; García de los Salmones et al., 2005; Abdullah \& Aziz, 2013). Most scholars agree that being honest and ethical generates confidence and safety to customers (García de los Salmones et al., 2005), thus deriving in more business volume for the company. In this study, customers' perceptions of the ethical behavior of companies was measured with indicators such as fairness, fulfillment of obligations, equity of services, and the existence of ethical principles and comprehensive codes of conduct within the organization.

The third dimension of the scale was named as relationship-building responsibilities. This factor consists of the items that highlight whether the company is working towards building longterm relationships that are more cohesive with its customers. Relationship-building responsibilities include corporate commitment to customers, giving them high priority (Turker, 2009), providing accessible services (El Akremi et al., 2015), working to increase customer loyalty (D'Aprile \& Talo, 2014), and knowing customer needs better (Pérez \& Rodríguez del Bosque, 2013). Relationship-building responsibilities mean treating customers as intelligent individuals who seek to make informed decisions about the products/services they purchase. Thus, providing relationship value is a major advancement in the evolving relationship between companies and their customers (Yeh, 2015).

Responsiveness consists of items that measure whether the company is responsive towards their customers' needs, being prompt in providing products/services and solving customer problems. Thus, responsiveness can be measured through items such as show of concern (Abdullah \& Aziz, 2013), responsiveness to complaints (Abdullah \& Aziz, 2013), resolution of complaints (Rohini \& Mahadevappa, 2010), establishment of formal procedures (Alvarado et al., 2017) or positive attitudes towards customers (D’Aprile \& Talò, 2014).

The fifth and last dimension of the scale refers to information-sharing responsibilities, which measure the extent to which companies are meeting their responsibility to keep customers informed of their products/services and other concerns. The emergence of information-sharing as a dimension of CSR clearly highlights the importance of information in shaping positive perceptions among customers. Pivato et al. (2008) noted that socially responsible companies that subject themselves to increased disclosure and provision of information are in a better position to build trust among customers. In this regard, using several sources of information can help the community as a whole to monitor a company. Therefore, customers can recognize a socially responsible company as better than a 'not CSR-oriented' company. Thus, information-sharing responsibilities hold importance since they can help in improving credibility, leading to favorable attitudes toward the company and promoting positive word-of-mouth among prospective customers (Eberle et al., 2013).

The evaluation of CSR towards customers based on the proposed scale can have significant implications for planning corporate CSR actions in the managerial sphere. First, the 5-dimensional 
model presented offers a practical way to measure customer perceptions of CSR. The scale focuses on actions that are key for companies to be judged socially responsible among customers. Thus, companies should pay attention to each and every one of the items presented in this scale if they aspire to position themselves with a good social image. Second, the scale can be used both descriptively and diagnostically. The scale can assist companies in better knowing customer perceptions of corporate CSR performance and, based on this knowledge, companies can use the information to identify the areas where they are not performing their responsibilities adequately. Thus, the scale can be used to explore the weakest areas of CSR performance, which will allow companies to improve the effectiveness of their CSR actions. Third, as CSR becomes more international each day, the scale has been devised in a way that it can address and provide evidence of CSR actions for companies operating in different parts of the world and in diverse cultures. Thus, the scale is applicable internationally and little adjustments can still be made to the dimensions and items in order to further enhance or represent the CSR construct in diverse cultures.

Finally, the research also has some limitations that should be mentioned. First, although the measurement tool proposed in this paper has been developed from the inputs of extant literature and the opinion of numerous academic experts and customers themselves, future studies may also involve experts from the business sector to broaden the range of informants and confirm the content validity of the scale to a greater extent. Second, the design of this research did not allow the gathering of longitudinal data. Thus, possible variations in customer perceptions of CSR before and after the usage of products/services could not be registered. Future studies may find the presented in this study useful to collect data at different points in time to assess how these perceptions may vary over time. Third, future research could also compare findings across different developing and/or developed countries. In doing so, the validity of the CSR scale proposed in this research could be generalized to different research settings. Fourth, the multidimensional structure of CSR towards customers that has been presented in this paper brings together actions and/or abilities to be taken/possessed at different organizational levels and/or functional areas within companies. Nonetheless, the discussion of the organizational structure that would be more adequate to effectively manage each CSR action identified in this study fell out of the research scope of the paper. Therefore, future studies that focus on discussing how companies could better structure their CSR strategy to improve customer perceptions of all the CSR actions identified in this paper would contribute to and enrich the academic discussion on CSR strategy significantly.

\section{Compliance with Ethical Standards:}

Funding: This study received no funding.

Ethical approval: All procedures performed in studies involving human participants were in accordance with the ethical standards of the institutional and/or national research committee and with the 1964 Helsinki declaration and its later amendments or comparable ethical standards.

Informed consent: Informed consent was obtained from all individual participants included in the study.

Conflict of Interest: The authors have no conflict of interest. 


\section{References}

Abdullah, Z., \& Aziz, Y. (2013). Institutionalizing corporate social responsibility: Effects on corporate reputation, culture, and legitimacy in Malaysia. Social Responsibility Journal, 9(3), 344-361.

Alvarado, A., Bigné, E., Aldás, J., \& Currás, R. (2017). A scale for measuring consumer perceptions of corporate social responsibility following the sustainable development paradigm. Journal of Business Ethics, 140(2), 243-262.

Bhardwaj, P., Chatterjee, P., Demir, K. D., \& Turut, O. (2018). When and how is corporate social responsibility profitable?. Journal of Business Research, 84, 206-219.

Boehe, D. M., \& Cruz, L. B. (2010). Corporate social responsibility, product differentiation strategy and export performance. Journal of Business Ethics, 91(2), 325-346.

Bowen, H. R. (1953). Social Responsibilities of the Businessman. New York, NY: Harper.

Brown, T. J., \& Dacin, P. A. (1997). The company and the product: Corporate associations and consumer product responses. Journal of Marketing, 61(1), 68-84.

Carroll, A. B. (1991). The pyramid of corporate social responsibility: Toward the moral management of organizational stakeholders. Business Horizons, July-August, 39-48.

Carroll, A. B. (2000). A commentary and an overview of key questions on corporate social performance measurement. Business \& Society, 39(4), 466-478.

Cassel, C. M., \& Hackl, P. (2000). On measurement of intangible assets: A study of robustness of partial least squares. Total Quality Management, 11(7), 897-907.

Commission of the European Communities (2003). What is Corporate Social Responsibility (CSR)?. Working paper [23 May 2003]. Accessed online: http://europa.eu.int/comm/ employment_social/soc-dial/csr/csr_whatiscsr.htm.

Chow, W., \& Chen, Y. (2012). Corporate sustainable development: Testing a new scale based on the mainland Chinese context. Journal of Business Ethics, 105(4), 519-533.

Churchill, G. A. (1979). A paradigm for developing better measures of marketing constructs. Journal of Marketing Research, 16(2), 64-73.

D’Aprile, G., \& Talò, C. (2014). Measuring corporate social responsibility as a psychosocial construct: A new multidimensional scale. Employee Responsibilities and Rights Journal, 26(3), 153-175.

Damanpour, F., Walker, R. M., \& Avellaneda, C. N. (2009). Combinative effects of innovation types and organizational performance: A longitudinal study of service organizations. Journal of management studies, 46(4), 650-675. 
Davenport, K. (2000). Corporate citizenship: A stakeholder approach for defining corporate social performance and identifying measures for assessing it. Business \& Society, 39(2), 210-219.

David, P., Kline, S., \& Dai, Y. (2005). Corporate social responsibility practices, corporate identity, and purchase intention: A dual process model. Journal of Public Relations Research, 17(3), 291-313.

Diamantopoulos, A., \& Siguaw, J. A. (2006). Formative versus reflective indicators in organizational measure development: A comparison and empirical illustration. British Journal of Management, 17(4), 263-282.

Dzansi, D. Y., \& Pretorius, M. (2009). The development and structural confirmation of an instrument for measuring the social responsibility of small and micro business in the African context. Social Responsibility Journal, 5(4), 450-463.

Eberle, D., Berens, G., \& Li, T. (2013). The impact of interactive corporate social responsibility communication on corporate reputation. Journal of Business Ethics, 118(4), 731-746.

El Akremi, A., Gond, J. P., Swaen, V., de Roeck, K., \& Igalens, J. (2015). How do employees perceive corporate responsibility? Development and validation of a multidimensional corporate stakeholder responsibility scale. Journal of Management, https://doi.org/10.1177/0149206315569311.

Ellen, P. S., Webb, D. J., \& Mohr, L. A. (2006). Building corporate associations: Consumer attributions for corporate socially responsible programs. Journal of the Academy of Marketing Science, 34(2), 147-157.

Fatma, M., Rahman, Z., \& Khan, I. (2014). Multi-item stakeholder based scale to measure CSR in the banking industry. International Strategic Management Review, 2(1), 9-20.

Fukukawa, K., Balmer, J. M. T., \& Gray, E. R. (2007). Mapping the interface between corporate identity, ethics and corporate social responsibility. Journal of Business Ethics, 76(1), 1-5.

Gallardo, D., \& Sánchez, M. I. (2014). Measuring corporate social responsibility for competitive success at a regional level. Journal of Cleaner Production, 72, 14-22.

García de los Salmones, M. M., Herrero, Á., \& Rodríguez del Bosque, I. (2005). Influence of corporate social responsibility on loyalty and valuation of services. Journal of Business Ethics, 61(4), 369-385.

Glavas, A., \& Kelley, K. (2014). The effects of perceived corporate social responsibility on employee attitudes. Business Ethics Quarterly, 24(2), 165-202.

Homburg, C., Krohmer, H., \& Workman Jr, J. P. (1999). Strategic consensus and performance: The role of strategy type and market-related dynamism. Strategic Management Journal, 20(4), 339-357. 
IBISWorld (2017). Global Wireless Telecommunications Carriers: Market Research Report. Accessed online: http://www.ibisworld.com/industry/global/global-wirelesstelecommunications-carriers.html.

Kanji, G. K., \& Chopra, P. K. (2010). Corporate social responsibility in a global economy. Total Quality Management, 21(2), 119-143.

Keeble, J. J., Topiol, S., \& Berkeley, S. (2003). Using indicators to measure sustainability performance at a corporate and project level. Journal of Business Ethics, 44(2), 149-158.

Kim, S., \& Ferguson, M. A. T. (2016). Dimensions of effective CSR communication based on public expectations. Journal of Marketing Communications, https://doi.org/10.1080/13527266.2015.1118143.

Latif, K. F. (2017). The Development and Validation of Stakeholder-Based Scale for Measuring University Social Responsibility (USR). Social Indicators Research, 1-37.

Lee, C. G., Sung, J., Kim, J. K., Jung, I. S., \& Kim, K. J. (2016). Corporate social responsibility of the media: Instrument development and validation. Information Development, 32(3), $554-565$.

Lee, M., \& Kim, W. (2013). The effect of perceived corporate social responsibility on hotel employee's attitude and behavior toward the organization. International Journal of Tourism Sciences, 13(3), 51-74.

Lichtenstein, D. R., Drumwright, M. E., \& Braig, B. M. (2004). The effect of corporate social responsibility on customer donations to corporate-supported nonprofits. Journal of Marketing, 68(4), 16-32.

Lim, R. E., Sung, Y. H., \& Lee, W. N. (2018). Connecting with global consumers through corporate social responsibility initiatives: A cross-cultural investigation of congruence effects of attribution and communication styles. Journal of Business Research, 88, 11-19.

Lu, C. S., Lin, C. C., \& Tu, C. J. (2009). Corporate social responsibility and organizational performance in container shipping. International Journal of Logistics: Research and Applications, 12(2), 119-132.

Maignan, I., \& Ferrell, O. C. (2000). Measuring corporate citizenship in two countries: The case of the United States and France. Journal of Business Ethics, 23(3), 283-297.

Marín, L., \& Ruiz, S. (2007). I need you too! Corporate identity attractiveness for consumers and the role of social responsibility. Journal of Business Ethics, 71, 245-260.

Marín, L., Ruiz, S., \& Rubio, A. (2009). The role of identity salience in the effects of corporate social responsibility on consumer behavior. Journal of Business Ethics, 84(1), 65-78. 
Martínez, P., Pérez, A., \& Rodríguez del Bosque, I. (2013). Measuring corporate social responsibility in tourism: Development and validation of an efficient measurement scale in the hospitality industry. Journal of Travel \& Tourism Marketing, 30, 365-385.

McWilliams, A., \& Siegel, D. (2001). Corporate social responsibility: A theory of the firm perspective. Academy of Management Review, 26(1), 117-127.

Mehralian, G., Nazari, J. A., Zarei, L., \& Rasekh, H. R. (2016). The effects of corporate social responsibility on organizational performance in the Iranian pharmaceutical industry: The mediating role of TQM. Journal of Cleaner Production, 135(1), 689-698.

Mohr, L. A., Webb, D. J., \& Harris, K. E. (2001). Do consumers expect companies to be socially responsible? The impact of corporate social responsibility on buying behavior. Journal of Consumer Affairs, 35(1), 45-72.

Mory, L., Wirtz, B. W., \& Göttel, V. (2016). Corporate social responsibility strategies and their impact on employees' commitment. Journal of Strategy and Management, 9(2), 172-201.

Öberseder, M., Schlegelmilch, B. B., Murphy, P. E., \& Gruber, V. (2014). Consumers' perceptions of corporate social responsibility: Scale development and validation. Journal of Business Ethics, 124(1), 101-115.

Palihawadana, D., Oghazi, P., \& Liu, Y. (2016). Effects of ethical ideologies and perceptions of CSR on consumer behavior. Journal of Business Research, 69(11), 4964-4969

Park, J., Lee, H., \& Kim, C. (2014). Corporate social responsibilities, consumer trust and corporate reputation: South Korean consumers' perspectives. Journal of Business Research, 67(3), 295-302.

Park, E., Kim, K. J., \& Kwon, S. J. (2017). Corporate social responsibility as a determinant of consumer loyalty: An examination of ethical standard, satisfaction, and trust. Journal of Business Research, 76, 8-13.

Pérez, A., \& Rodríguez del Bosque, I. (2013). Measuring CSR image: Three studies to develop and to validate a reliable measurement tool. Journal of Business Ethics, 118(2), 265-286.

Pérez, A., Martínez, P., \& Rodríguez del Bosque, I. (2013). The development of a stakeholderbased scale for measuring corporate social responsibility in the banking industry. Service Business, 7(3), 459-481.

Pivato, S., Misani, N., \& Tencati, A. (2008). The impact of corporate social responsibility on consumer trust: The case of organic food. Business Ethics: A European Review, 17(1), 312.

Pomering, A., \& Dolnicar, S. (2009). Assessing the prerequisite of successful CSR implementation: Are consumers aware of CSR initiatives?. Journal of Business Ethics, 85, 285-301. 
Quazi, A. M., \& O'Brien, D. (2000). An empirical test of a cross-national model of corporate social responsibility. Journal of Business Ethics, 25(1), 33-51.

Quazi, A., Amran, A., \& Nejati, M. (2016). Conceptualizing and measuring consumer social responsibility: A neglected aspect of consumer research. International Journal of Consumer Studies, 40(1), 48-56.

Reverte, C., Gómez, E., \& Cegarra, J. G. (2016). The influence of corporate social responsibility practices on organizational performance: Evidence from eco-responsible Spanish firms. Journal of Cleaner Production, 112, 2870-2884.

Rodrigues, P., \& Borges, A. P. (2015). Corporate social responsibility and its impact in consumer decision-making. Social Responsibility Journal, 11(4), 690-701.

Rohini, R., \& Mahadevappa, B. (2010). Social responsibility of hospitals: An Indian context. Social Responsibility Journal, 6(2), 268-285.

Sen, S., \& Bhattacharya, C. B. (2001). Does doing good always lead to doing better? Consumer reactions to corporate social responsibility. Journal of Marketing Research, 38(2), 225243.

Sen, S., Bhattacharya, C. B., \& Korschun, D. (2006). The role of corporate social responsibility in strengthening multiple stakeholder relationships: A field experiment. Journal of the Academy of Marketing Science, 34(2), 158-166.

Singhapakdi, A., Kraft, K. L., Vitell, S. J., \& Rallapalli, K. C. (1995). The perceived importance of ethics and social responsibility on organizational effectiveness: A survey of marketers. Journal of the Academy of Marketing Science, 23(1), 49-56.

Singhapakdi, A., Vitell, S. J., Rallapalli, K. C., \& Kraft, K. L. (1996). The perceived role of ethics and social responsibility: A scale development. Journal of Business Ethics, 15(11), 11311140.

Skudiene, V., \& Auruskeviciene, V. (2012). The contribution of corporate social responsibility to internal employee motivation. Baltic Journal of Management, 7(1), 49-67.

Starrett, R. H. (1996). Assessment of global social responsibility. Psychological Reports, 78(2), 535-554.

Sun, W., \& Price, J. M. (2016). The impact of environmental uncertainty on increasing customer satisfaction through corporate social responsibility. European Journal of Marketing, 50(7/8), 1209-1238.

Taghian, M., D’Souza, C., \& Polonsky, M. (2015). A stakeholder approach to corporate social responsibility, reputation and business performance. Social Responsibility Journal, 11(2), 340-363. 
Turker, D. (2009). Measuring corporate social responsibility: A scale development study. Journal of Business Ethics, 85(4), 411-427.

Valentine, S., \& Fleischman, G. (2008). Ethics programs, perceived corporate social responsibility and job satisfaction. Journal of Business Ethics, 77(2), 159-172.

Vitell, S. J. (2015). A case for consumer social responsibility (CnSR): Including a selected review of consumer ethics/social responsibility research. Journal of Business Ethics, 130(4), 767774.

Wasko, M. M., \& Faraj, S. (2005). Why should I share? Examining social capital and knowledge contribution in electronic networks of practice. MIS Quarterly, 29(1), 35-57.

Webb, D. J., Mohr, L. A., \& Harris, K. E. (2007). A re-examination of socially responsible consumption and its measurement. Journal of Business Research, https://doi.org/10.1016/j.jbusres.2007.05.007.

Wood, D. J. (2010). Measuring corporate social performance: A review. International Journal of Management Reviews, 12(1), 50-84.

Yeh, Y. P. (2015). Corporate social responsibility and service innovation on customer loyalty: An empirical investigation in wealth management services. International Journal of Bank Marketing, 33(6), 823-839. 